\title{
Plasmacytoma in the Oral Cavity: A Case Report
}

\author{
Plasmocitoma en la Cavidad Oral: Reporte de Caso
}

\author{
Tarley Pessoa de Barros*; Fabio Moschetto Sevilha*; Daniela Vieira Amantea*; \\ Gabriel Denser Campolongo*; Laurindo Borelli Neto*; Nilton Alves ${ }^{* * *+*}$ \& Reinaldo José de Oliveira*
}

BARROS, T. P.; SAVILHA, F. M.; AMANTEA, D. V.; CAMPOLONGO, G. D.; NETO, L. B.; ALVES, N. \& OLIVEIRA, R. J. Plasmacytoma in the oral cavity: A case report. Int. J. Odontostomat., 5(2):115-118, 2011.

\begin{abstract}
The plasma cell neoplasms may present in soft tissue as extramedullary plasmacytoma (EMP), in bone as a solitary plasmacytoma of bone (SPB), or as part of the multifocal disseminated disease multiple myeloma (MM). The EMP is rare, comprising around $3 \%$ of all plasma cell neoplasm. The majority (80\%) occurs in the head and neck region. In this study we report a case of a man, 70 years old, melanoderm, with a lesion of the oral cavity. Upon physical examination, a lesion was found that extended throughout the posterior upper alveolar ridge, as far as the maxillary tuber on the left side, extending towards the palate. Radiographic examination, complementary laboratory exams were performed. Based on the conclusive symptoms of plasmacytoma, the patient was referred to the hematology service for treatment with local radiotherapy. The patient responded satisfactorily to the treatment, and after 15 months, all clinical symptoms of the lesion in the oral cavity had disappeared.
\end{abstract}

KEY WORDS: plasma cell neoplasms, extramedullary plasmacytoma, bone marrow, oral cavity.

\section{INTRODUCTION}

The plasma cell neoplasms may present in soft tissue as extramedullary plasmacytoma (EMP), in bone as a solitary plasmacytoma of bone (SPB), or as part of the multifocal disseminated disease multiple myeloma (MM). These tumors are derived from bone marrow stem cells of B-Lymphocyte lineage, and are characterized by an expansion of a clone of immunoglobulin-secreting cells (Regezi et al., 2003).

Multiple Mieloma (MM). The MM represents the most important and common plasma cell dyscrasia (Regezi et al.), involving large numbers of bone (Shafer et al., 1974). Also known as generalized myeloma or myelomatosis, its etiology is unknown, it is characterized by the proliferation of cells that have the microscopic appearance of plasmacytes (Anil, 2007). It is considered a multifocal plasma cell cancer of the skeleton, but it may also affect extraskeletal sites during its progression (Dores et al., 2009). The disease begins insidiously in bone marrow, and by the time it is diagnosed it is usually at an advanced stage. Extramedullary manifestations sometimes occur during the course of the disease in the form of a tumor mass consisting predominantly of plasmacytes surrounded by a fine reticular network (Nasr Ben Ammar et al., 2010).

Extramedullary Plasmacytoma (EMP). Shafer et al., affirm that the MM and EMP presents similar histological features, however, the EMP is characterized by an extramedullary located mass infiltrated by monoclonal plasma cells without signs of MM elsewhere in the body (Dimopoulos et al., 1999).

The EMP is rare, comprising around $3 \%$ of all plasma cell neoplasm (Dimopoulos et al.). The majority $(80 \%)$ occurs in the head and neck region (Regezi et al.), in particularly, in the nasopharynx, paranasal sinuses and tonsils (75\%). The EMP occurs less commonly, in the oropharynx (12\%) (Goel et al., 2010). It accounts for around $4 \%$ of non-epithelial neoplasms of the nasal cavity, paranasal sinuses, and nasopharynx (Regezi et al.), occurring mainly in the fifth and sixth decades of life, with a higher prevalence in men (Gross et al., 2004; Nasr Ben Ammar et al.). The incidence is higher among individuals of advanced

\footnotetext{
* Universidade Bandeirante de São Paulo - UNIBAN, Brazil

* Universidade Estadual Paulista - UNESP, Araraquara, Brazil

** Universidad Autónoma de Chile, Talca, Chile.
} 
age, with a mean age at diagnosis of 64 years, and two times higher among melanoderm individuals than caucasian (Nasr Ben Ammar et al.).

The signs and symptoms of plasmacytoma are pain, swelling, and tissue masses obstructing the respiratory tract or oral cavity that cause a local expansion by edema (Gross et al.). When it occurs in the nasopharynx, the main symptom is progressive nasal obstruction and intermittent epistaxis, and in the maxillary sinus, it presents enlarged volume and may affect and damage the adjacent teeth, due to destruction of the surrounding bone (Ersoy et al., 2004). Other symptoms may appear depending on the location of the tumor. Edema is the most common complaint, and pain may also be present when the adjacent bone is affected. Discomfort or pain of the tooth can occur when there is involvement of the dental alveolus.

The most widely accepted treatment is chemotherapy with cyclophosphamide, melphalan, and steroid protocols. Radiotherapy may also be used since the tumor is radiosensitive (eradicable at a dose of 4.000 to $5.000 \mathrm{cGy}$ ). Another alternative is surgical resection (Romero et al., 2009).

The aim of this study is to report a case of plasmacytoma with exteriorization to the oral cavity.

\section{CASE REPORT}

Male patient, 70 years old, melanoderm, was received at the Bucomaxillofacial Surgery and Traumatology Service of a public hospital located in São Paulo - Brazil, with a lesion in the oral cavity.

The patient reported rapid, painless growth of the lesion, and confirmed that he had been a smoker for 62 years. He denied alcohol consumption and did not know whether he had any systematic disease. The patient had been medicated with antibiotics for 14 days without regression of the lesion.

Upon physical examination, a lesion was found that extended throughout the posterior upper alveolar ridge, as far as the maxillary tuber on the left side, extending towards the palate (Fig. 1). The base was sessile, erythematous, and flaccid on palpation. On the radiographic examination, the maxillary sinus was foggy, with bone impairment. The complementary laboratory exams were normal.

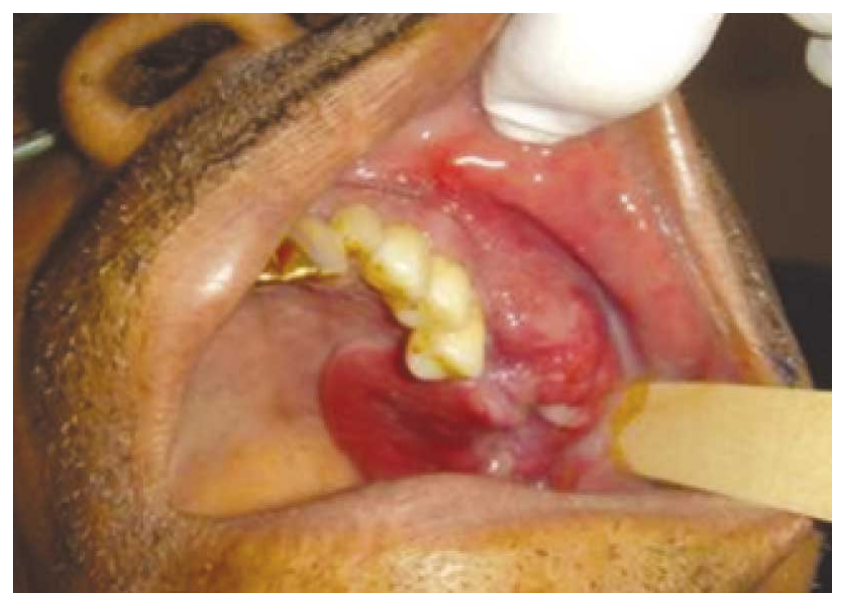

Fig. 1. Lesion in the posterior upper alveolar ridge, as far as the maxillary tuber on the left side, extending towards the palate.

The patient was referred to the surgical center for incisional biopsy of the lesion, and the fragment was sent for anatomopathological examination. The exam results showed fibroadipose tissue with infiltration of small atypical cells, requiring complementary immunohistochemical exam. In this latter exam, histological aspects of a plasmacytoma were observed, with evidence of cell differentiation into kappa chains. Tumor cells were positive for Ki-67, Mib-1; CD45; Bci-2; and positive diffused for CD-138.

Based on the conclusive symptoms of plasmacytoma, the patient was referred to the hematology service for treatment with local radiotherapy (at a dose of 4000 to 5000 cGy).

The patient responded satisfactorily to the treatment, and after 15 months, all clinical symptoms of the lesion in the oral cavity had disappeared (Fig. 2). He is still in follow-up care.

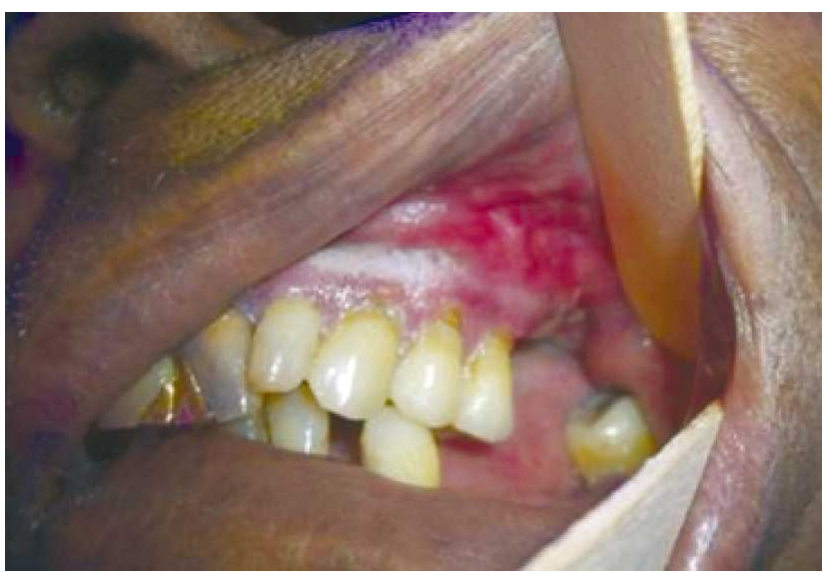

Fig. 2. Oral cavity of the patient showing good results for remission of the lesion. 


\section{DISCUSSION}

The majority of patients with extramedullary plasmacytoma are male (63\%-86\%). This neoplasm is most common in the sixth to eighth decade, and the head and the neck are the regions most commonly affected, $56 \%$ to $90 \%$ was disease free at 10 years, and the median survival was 8 to 20 years (Knowling et al., 1983; Shih et al., 1995; Bolek et al., 1996; Liebross et al., 1999; Galieni et al., 2000). In other studies the median survival rate was 5.66 years (Susnerwala et al., 1997).

Plasmacytoma is a clinical finding that is difficult to diagnose. Only the anatomopathological exam, preferably accompanied by an immunohistochemical study (Romero et al.), can confirm the diagnosis through positive plasma cells that express CD38 with concomitant cytoplasmic expression of kappa or lambda light chains (Dimopoulos et al.). In our case, incisional biopsy was carried out, with confirmation for kappa chains, CD45, CD138 and negative confirmation for lambda light chains.

Some authors affirm that approximately 10$30 \%$ of treated patients distant failure seem to occur (Corwin \& Lindberg, 1979; Holland et al., 1992; Susnerwala et al.). This takes place on average within 2 to 3 years after diagnosis (Knowling et al.; Liebross et al.; Galieni et al.; Straetmans \& Stokroos, 2008). Dimopoulos et al. affirms that the prognosis of patients with solitary extramedullary plasmacytoma (SEP) appears to be better than for patients with SBP because approximately $70 \%$ of patients with SEP remain disease-free at 10 years. Mock et al. (1987) suggested that the cases with lambda light chain may be more immature and more likely to progress to MM. In other study, Susnerwala et al. observed that the cases that progressed to MM showed kappa light chain restriction. In our study the patient presents the kappa light chain, however there was no evidence of progression to MM. Holland et al. affirms that the lesion size, total serum protein levels, and the presence of a monoclonal spike on serum electrophoresis may be of prognostic significance in identifying those solitary lesions that ultimately will convert to MM.

Susnerwala et al. affirms that the higher grade tumors were generally associated with more bulky disease. There is every indication that plasmacytomas that emerge from the soft tissues of the nasopharynx, oral cavity, or larynx, and do not involve adjacent bone, have a better prognosis than those located in areas such as the maxillary, mandible, alveolus and others (Romero et al.).

As EMP are highly radiosensitive, almost all patients obtained successful treatment with local control (Weber, 2005). Radiation therapy is the most effective form of local treatment in the management of solitary plasmacytomas. The recommended dose of radiation is 40 to $60 \mathrm{~Gy}$ (Corwin \& Lindberg; Holland et al.; Romero et al.; Nasr Ben Ammar et al.). Weber and Soutar et al. (2004) recommend that for EMP $<5$ $\mathrm{cm}$ a radiotherapy dose of $40 \mathrm{~Gy}$ in 20 fractions, and recommend for bulky EMP of $>5 \mathrm{~cm}$, a higher dose of up to $50 \mathrm{~Gy}$ in 25 fractions. The appropriate therapy results in long-term stability and potential cure in approximately $67 \%$ of patients (Weber).

In conclusion, plasmacytoma, despite being a lesion with slow, asymptomatic growth, can assume large volumes, making proper treatment difficult. When there is no bone involvement and it is diagnosed early, the success of treatment is generally higher. The treatment of choice is radiotherapy, with good results for remission of the lesion, as we have demonstrated in this case study.

BARROS, T. P.; SAVILHA, F. M.; AMANTEA, D. V.; CAMPOLONGO, G. D.; NETO, L. B.; ALVES, N. \& OLIVEIRA, R. J. Plasmocitoma en la cavidad oral: reporte de caso. Int. J. Odontostomat., 5(2):115-118, 2011.

RESUMEN: La neoplasia de células plasmáticas se presenta en los tejidos blandos como plasmocitoma extramedular (EMP), en el hueso como plasmocitoma solitario (SPB), o como parte de una enfermedad diseminada, el mieloma múltiple (MM). EI EMP es poco frecuente, manifestandose en alrededor de un 3\%. Se presentan generalmente (80\%) en las regiones de cabeza y cuello. En este reporte de caso, un hombre de 70 años, melanoderma, presentaba una lesion en la cavidad oral. En el examen físico se observó la lesión a lo largo de la parte posterior del reborde alveolar superior, en la tuberosidad maxilar en el lado izquierdo hacia el paladar. Se realizaron exámenes radiográficos y de laboratorio. Con base en los signos de plasmocitoma, el paciente fue referido a tratamiento con radioterapia. El tratamiento fue muy exitoso y después de 15 meses se observó que el paciente no presentaba los signos clínicos característicos de la lesión neoplásica.

oral.

PALABRAS CLAVE: neoplasia de células plasmáticas, plasmocitoma extramedular, médula ósea, cavidad 


\section{REFERENCES}

Anil, S. Solitary plasmacytoma of the maxilla--a case report and review of the literature. Gen. Dent., 55(1):39-43, 2007.

Bolek, T. W.; Marcus, R. B. \& Mendenhall, N. P. Solitary plasmacytoma of bone and soft tissue. Int. J. Radiat. Oncol. Biol. Phys., 36(2):329-33, 1996.

Corwin, J. \& Lindberg, R. D. Solitary plasmacytoma of bone vs. extramedullary plasmacytoma and their relationship to multiple myeloma. Cancer, 43(3):1007-13, 1979.

Dimopoulos, M. A.; Kiamouris, C. \& Moulopoulos, L. A. Solitary plasmacytoma of bone and extramedullary plasmacytoma. Hematol. Oncol. Clin. North Am., 13(6):1249-57, 1999.

Dores, G. M.; Landgren, O.; McGlynn, K. A.; Curtis, R. E.; Linet, M. S. \& Devesa, S. S. Plasmacytoma of bone, extramedullary plasmacytoma, and multiple myeloma: incidence and survival in the United States, 1992-2004. Br. J. Haematol., 144(1):86-94, 2009.

Ersoy, O.; Sanlier, T.; Yigit, O.; Halefoglu, A. M.; Ucak, S. \& Altuntas, Y. Extramedullary plasmacytoma of the maxillary sinus. Acta Otolaryngol., 124(5):642-4, 2004.

Galieni, P.; Cavo, M.; Pulsoni, A.; Avvisati, G.; Bigazzi, C.; Neri, S.; Caliceti, U.; Benni, M.; Ronconi, S. \& Lauria, F. Clinical outcome of extramedullary plasmacytoma. Haematologica, 85(1):47-51, 2000.

Goel, G.; Rai, S.; Naik, R.; Gupta, A.; Baliga, P. \& Sinha, R. Cytodiagnosis of extramedullary plasmacytomas. Acta Cytol., 54(3):255-8, 2010.

Gross, M.; Eliashar, R.; Maly, B. \& Sichel, J. Y. Maxillary sinus plasmacytoma. Isr. Med. Assoc. J., 6(2):119-20, 2004.

Holland, J.; Trenkner, D. A.; Wasserman, T. H. \& Fineberg, B. Plasmacytoma. Treatment results and conversion to myeloma. Cancer, 69(6):1513-7, 1992.

Knowling, M. A.; Harwood, A. R. \& Bergsagel, D. E. Comparision of extramedullary plasmacytomas with solitary and multiple plasma cell tumors of bone. J. Clin. Oncol., 1(4):255-62, 1983.

Liebross, R. H.; Ha, C. S.; Cox, J. D.; Weber, D.; Delasalle, K. \& Alexanian, R. Clinical Course of extramedullary plasmacytoma. Radiother. Oncol., 52(3):245-9, 1999.

Mock, P. M.; Neal, G. D. \& Aufdemorte, T. B. Immunoperoxidase characterisation of extramedullary plasmacytoma of the head and neck. Head Neck Surg., 9(6):356-61, 1987.
Nasr Ben Ammar, C.; Ghorbel, I.; Kochbati, L.; Gargouri, W.; Touati, S. \& Maalej, M. Solitary and extramedullary plasmacytoma in the head and neck region: five cases report. Cancer Radiother., 14(8):755-8, 2010.

Regezi, J. A.; Sciubba, J. J. \& Jordan, R. C. K. Oral Pathology: Clinical Pathologic Correlations. $4^{\text {th }}$ Edn. Philadelphia, W. B. Saunders, 2003.

Romero, I. L.; Campos, F. A. G.; Damasceno, R. W. F.; Vital Filho, J. \& Bison, S. H. D. V. F. Plasmocitoma da órbita envolvendo glândula lacrimal com transformação secundária para mieloma múltiplo: relato de caso. Arq. Bras. Oftalmol., 72(2):236-8, 2009.

Shafer, W. G.; Hine, M. K. \& Levy, B. M. Patologia bucal. 3ª ed. Rio de Janeiro, Interamericana, 1974.

Shih, L. Y.; Dunn, P.; Leung, W. M.; Chen, W. J. \& Wang, P. N. Localised plasmacytomas in Taiwan: comparison between extramedullary plasmacytoma and solitary plasmacytoma of bone. Br. J. Cancer, 71(1):128-33, 1995.

Soutar, R.; Lucraft, H.; Jackson, G.; Reece, A.; Bird, J.; Low, E. \& Samson, D. Guidelines Working Group of the UK Myeloma Forum; British Committee for Standards in Haematology; British Society for Haematology. Br. J. Haematol., 124(6):717-26, 2004.

Straetmans, J. \& Stokroos, R. Extramedullary plasmacytomas in the head and neck region. Eur. Arch. Otorhinolaryngol., 265(11):1417-23, 2008.

Susnerwala, S. S.; Shanks, J. H.; Banerjee, S. S.; Scarffe, J. H.; Farrington, W. T. \& Slevin, N. J. Extramedullary plasmacytoma of the head and neck region: clinicopathological correlation in 25 cases. Br. J. Cancer, 75(6):921-7, 1997.

Weber, D. M. Solitary bone and extramedullary plasmacytoma. Hematology Am. Soc. Hematol. Educ. Program., 373-6, 2005.

Correspondence to:

Tarley Pessoa de Barros

Universidade Bandeirante de São Paulo

Rua Guarara, 316 - Jardim Paulistano

São Paulo (SP)

BRASIL

Email: tpbarros@uol.com.br

Received: 29-05-2011

Accepted: 02-07-2011 